solely on the proportion $b / \sqrt{ }(a+b) \cdot(b+c)$, and there seems no reason why this proportion should tend to be lowered by chance fluctuations in the cell-division.
The memoir concludes with twelve pages of tables containing all the measurements taken, and the two parts together should form a classic in the growing literature of the subject.

\title{
Obituary
}

\section{DR. Sydney A. KAY}

$\mathrm{S}^{\mathrm{Y}}$ YDNEY ALEXANDER KAY was born in Dundee in 1874 and after leaving the High School became a student at University College, Dundee, under Prof. (now Sir) James Walker. The association thus begun continued through most of Kay's life. His student career was a brilliant one - he gained the medals in chemistry, natural philosophy, mathematics and physiology. Graduating as B.Sc. in 1896, he engaged in research with Walker, and two papers-"On the so-called Magnesium Hypoiodite" (Proc. Roy. Soc. Edin., 21,236 ; 1896) and "Velocity of Urea Formation in Aqueous Alcohol"' (J. Chem. Soc., 71, 489 ; 1897)-recorded the investigations. The award of an 1851 Fxhibition scholarship enabled him to study under Arrhenius at Stockholm and under Ostwald at Leipzig. The work done at Stockholm furnished material for a lengthy paper on "Equilibrium between Sulphuric Acid and Sulphates in Aqueous Solution" (Proc. Roy. Soc. Edin., 22, 484 ; 1899).

The next ten years were spent at St. Andrews, where Kay proved himself a most efficient assistant to Prof. Purdie and an extraordinarily conscientious teacher. Perhaps one might say that conscientiousness was his outstanding quality. While at St. Andrews the degree of D.Sc. was conferred upon him in 1902, and three years later he became a fellow of the Chemical Society, London.

On the retirement of Prof. Purdie in 1909, Kay transferred to Edinburgh; once more to be associated with Walker, who had succeeded Crum Brown in the chair of chemistry in the previous year. He devoted himself anew to teaching and more especially the teaching of chemical analysis. The textbook-Cumming and Kay's "Quantitative Chemical Analysis"-first appeared in 1913, the fifth edition in 1928 and, at the time of his death, Kay was looking forward to a term's leave of absence to be occupied in bringing out a completely revised edition of the book. Another volume by Kay alone appeared in 1921 under the title "Qualitative Analysis of Inorganic Substances". He became much interested in water analysis and with Walker published "The Acidity and Alkalinity of Natural Waters" (J. Soc. Chem. Ind., 31, 1013; 1912) and with Susan H. Newlands "Determination of the Hardness of Natural Waters and the Use of Methyl Red as an Indicator" and "The Determination of Calcium and Magnesium in Natural Waters" ( $J$. Soc. Chem. Ind., 35, 445 and $447 ;$ 1916). During the second half of the War he did good service as deputy inspector of high explosives for the south of Scotland.
Kay was appointed a lecturer in chemistry in 1914 and from 1922 gave lectures to the agriculture and forestry students and was in charge of the Advanced Inorganic Laboratory. From him, many students learned method and accuracy and the value of skilful manipulation.

Kay was a lover of Nature and his vacations were generally spent in the Highlands, where he found great happiness in the study of wild life. His skill with the camera was notable and he was at one period presiclent of the St. Andrews Amateur Photographic Society. In 1905 he married Margaret Frazer Plenderleath. The union proved a happy one and the sympathy of his colleagues and friends goes out to her in her great beroavement. After a very brief illness Dr. Kay died on May 26, and those of us who knew him have lost a true friend.

$$
\text { J. F. M. }
$$

\section{Dr. Norman U. MkLdrum}

THE death of Dr. Norman Urquhart Meldrum on June 7, at the early age of twenty-five years, has robbed biochemistry of an exceptionally active and brilliant young worker. A month earlier he had had a riding accident, from the effects of which he had not fully recovered. He was educated at the University of Edinburgh, where he took his B.Sc. degree in 1928 . In the same year he became a member of Emmanuel College, Cambridge, and joined the Biochemical Laboratory with a grant from the Carnegie Fund. In 1930 he obtained a Beit fellowship (for medical research) which he held until his death. He took the Cambridge Ph.D. in 1931 .

Immediately after the isolation of crystalline tripeptide glutathione by Hopkins in 1929, Meldrum and Dixon investigated its properties, and found that these differed unexpectedly from those of Hopkins's amorphous preparation of 1921. Until his death Meldrum continued working on the properties and functions of glutathione in the organism, but published no other large papers on the subject. He also gave some attention to other problems such as the denaturation of proteins.

After taking his doctor's degree, Meldrum joined Roughton in his investigation of the carbon dioxide catalyst present in blood. This co-operation speedily led to the isolation of a new enzyme, carbonic anhydrase, the study of which has opened up a large new field of work (see NaTURE of June 17, p. 874). Meldrum's biochemical knowledge was of the greatest value in this research.

Meldrum had a real genius for getting to the heart of a biochemical problem and it was this, 